\title{
The Scottish motor neuron disease register: a prospective study of adult onset motor neuron disease in Scotland. Methodology, demography and clinical features of incident cases in 1989
}

\author{
The Scottish Motor Neuron Disease Research Group
}

J E C Hern

R Knight

Dundee

D Davidson

A Forster

R Roberts

R J Swingler

Edinburgh

B Ashworth

A M Chancellor

R E Cull

H Fraser

E H Jellinek

S M Holloway

A McInnes

B Pentland

P A G Sandercock

C P Warlow

R Will

Glasgow

J P Ballantyne

P O Behan

I Bone

I Draper

W F Durward

G Jamal

$P$ Kennedy

R Metcalfe

$M$ Thomas

A I Weir

Inverness

L R Fisher

Correspondence to:

Dr Chancellor.

Received 20 June 1991 and in final revised form 5 September 1991 . Accepted 18 September 1991

The motor neuron diseases (MND) occur at any age but most of the childhood forms (spinal muscular atrophies) are familial, and a result of a mutation on the long arm of chromosome $5 .^{1}$ In contrast, although some forms of adult onset MND have a genetic basis, ${ }^{2}$ with linkage to chromosome $21,{ }^{3}$ the vast majority are sporadic. Numerous diverse theories of aetiology have been summarised in recent reviews ${ }^{4-6}$ but there is still no universally accepted cause or effective treatment. Amyotrophic lateral sclerosis (ALS), progressive bulbar palsy (PBP), and progressive muscular atrophy (PMA), the principal subtypes, are almost certainly clinical variants of a single disease $^{6}$ with the common underlying pathological finding of anterior horn cell degeneration. Primary lateral sclerosis (PLS), a much debated but probably true entity, may be a separate disorder. ${ }^{7}$

The incidence of MND may not be as static or as uniform as was once believed. ${ }^{8}$ If the distribution of the disease in time and place is changing then this might provide clues to its cause. There is evidence for an environmental influence in the Western Pacific forms of MND which has largely been derived from epidemiological studies, ${ }^{10}$ and together with the low concordance in twin studies, ${ }^{11}$ suggests that

\begin{abstract}
The Scottish Motor Neuron Disease Research Group

Aberdeen

Abstract

The Scottish Motor Neuron Disease Register (SMNDR) is a prospective, collaborative, population based study of motor neuron disease (MND) in Scotland. The register started in January 1989 with the aim of studying the clinical and epidemiological features of MND by prospectively identifying incident patients. It is based on a system of registration by recruitment from multiple sources, followed by the collection of complete clinical data and follow up, mainly through general practioners. In this report the register's methodology and the demography and incidence data for the first year of study are presented. One hundred and fourteen newly diagnosed patients were identified in 1989 giving a crude incidence for Scotland of $2 \cdot 24 / 100$ 000/year. Standardised incidence ratios showed a non-significant trend towards lower rates in north eastern regions and island areas.
\end{abstract}

factors other than genetic might be important in sporadic MND in developed countries.

A study design ensuring complete case ascertainment is of major importance when seeking putative environmental factors by studying variation of incidence in time and place. Clinical surveys from specialised centres are likely to be biased and death certificate data inaccurate. The Scottish Motor Neuron Disease Register (SMNDR) was established in January 1989 with the aim of prospectively studying the epidemiology of this disease in Scotland by registering and following up al incident cases presenting to medical attention. Scotland is a suitable country because it is geographically and demographically well defined; few patients are likely to get health care outside the country; almost all individuals are registered with a general practitioner (GP); a centralised medical records system means that medical records are transferred if the patient moves between areas or can be traced in the United Kingdom with the National Health Service Register; population denominators are well defined and, importantly, the number of cases coming to our attention every year is such that complete and detailed documentation is possible in all cases.

Scotland is in the north of the United Kingdom and covers an area of roughly $78772 \mathrm{~km}^{2} .^{12}$ The population estimate for 1989 was $5090700,18 \%$ of whom were over 65 years. ${ }^{13}$ The country is divided into nine regions, three island areas, 53 districts and 1211 postcode sectors and is served by 3041 GPs. Neuromedical services are provided by 19 consultant neurologists and four consultant clinical neurophysiologists who are likely to see most, but not all, patients with MND.

\section{Methods}

1) All consultant neurologists and neurophysiologists in Scotland agreed to collaborate and were the main source of case notification. They were requested to complete a simple registration form (table 1) which was forwarded to the study coordinators based at the Western General Hospital, Edinburgh, for inclusion on a centralised database. Collaborators were encouraged to register patients when the diagnosis of MND was first made so that suspected, as well as definite cases, could be followed up. The threshold of individual col- 
Table 1 Registration form details

\begin{tabular}{l} 
(Responses: yes, no, uncertain) \\
General principles: \\
Muscular weakness \\
Progressive history \\
Absence of sensory signs \\
Seen by a neurologist \\
Anatomical classification: \\
Bulbar signs \\
UMN bulbar signs \\
LMN bulbar signs \\
Limb signs \\
UMN limb signs \\
LMN limb signs \\
EMG performed? \\
Is there any suggestion of an alternative diagnosis? \\
Is there any associated disorder? \\
Is the patient aware of the diagnosis? \\
Date of onset \\
Date of diagnosis \\
Is the diagnosis definite/probable/suspected? \\
\hline
\end{tabular}

laborators with respect to the registration of suspected cases varied.

2) The two family care officers employed by the Scottish Motor Neurone Disease Association (SMNDA) offered patients the option of self-referral to the register.

3) In 1990 a letter was sent to all GPs in Scotland asking for details of any patients in their practice diagnosed with MND after 1 January 1989.

4) The information and statistics division of the Common Service Agency for the Scottish Health Service provided a list of all patients discharged from Scottish hospitals in 1989 coded by International Classification of Diseases (ICD) 9 as code 335 (anterior horn cell disease). The records of all patients older than 15 years, not already included on the register, were obtained and reviewed before inclusion. 5) A request was made to neuropathology departments for any patients diagnosed with MND at postmortem examination.

6) All death certificates for 1989 identified from the General Register Office for Scotland were examined when ICD-9 335 was recorded as the underlying cause of death or as a contributing factor. GP practice records with letters and summaries from hospital consultations were then requested from health boards.

After registration clinical details included in discharge summaries or outpatient correspondence and the reports of neurophysiological investigations were obtained to allow classification of MND subtypes based on clinical features (see below). After a patient's death the complete hospital and GP records were scrutinised and pathology reports obtained where available.

Patients were included on the register if the diagnosis of MND had been made or suggested for the first time after 31 December 1988. At registration, the patient's GP was informed of the aims of the study. Follow up of all patients was achieved mainly through GPs using a six monthly questionnaire. The questionnaire highlighted any revision of the diagnosis, any change of GP (to allow transfer of follow up), and simple clinical features such as difficulty with speaking or swallowing, limb weakness and the date of death. Collaborators, informed of the study's progress by a monthly newsletter, were encouraged to send copies of follow up correspondence from hospital clinics. A paper file is maintained for each patient. A dBase IV computer system was used to construct a database for compiling features of key interest and permitting organised retrieval of data.

The 1989 population estimate for Scotland and its regions ${ }^{13}$ (derived from the last population census in 1981) was used for the calculation of rates and standardised incidence ratios. Age specific incidence was calculated using age at diagnosis, usually in relation to the first admission to hospital for investigations. The significance of differences between the means for ages according to sex was examined using the Students $t$ test. Age adjusted standardised incidence ratios (of observed to expected cases) were calculated for each of the nine regions and three island areas using the indirect method. ${ }^{14}$ Confidence intervals $(\mathrm{CI})$ were calculated using the confidence intervals analysis programme. ${ }^{15}$

DIAGNOSTIC CRITERIA

There are no universally accepted criteria for the diagnosis of MND. A subcommittee of the World Federation of Neurology (WFN) proposed a set of criteria for the diagnosis of ALS but these criteria are too complicated for general epidemiological use as they are difficult to follow and depend on very detailed correlation of clinical, electrophysiological and laboratory data. We devised a set of simple but specific criteria suitable for applying to this study, and other large scale studies, using aspects of the WFN approach. The criteria for diagnosis are as follows: the term "motor neuron disease" is used to encompass any adult ( $>15$ years) onset progressive motor system disorder (sporadic or familial). The following categories are identified:

\section{1) Clinically definite $M N D$}

A combination of lower motor neuron (LMN) signs, clinically or by electromyography (EMG), and upper motor neuron (UMN) signs (table 2), not due to longstanding neurological disease, involving the brainstem and one or more spinal regions (cervical, thoracic, lumbosacral). If signs were limited to the brainstem and only one spinal region, then both $\mathrm{UMN}$ and $\mathrm{LMN}$ signs were required in that region, otherwise it was not considered necessary for both UMN and LMN signs to be present in all involved regions. This was qualified further by the following mandatory criteria: a progressively deteriorating course of the disease; absence of sensory signs (including visual abnormalities) apart from mild vibration sense loss in the elderly; absence of sphincteric disturbance; Parkinsonism; dementia and causes of syndromes which may mimic MND, after appropriate investigations and follow up. Normal or brisk reflexes in the presence of a clearly wasted limb were used as evidence of UMN involvement.

Patients in this group were assigned a category which gave an indication of the 
Table 2 Physical signs by region used in the classification of patients

\begin{tabular}{lll}
\hline Region & Upper motor neuron (UMN) signs & Lower motor neuron (LMN) signs \\
\hline Bulbar & Dysarthria (may be LMN) & Wasted tongue or cranial musculature \\
& Dysphagia (may be LMN) & Fasciculation of the tongue \\
& Spastic, clumsy tongue & Dysphonia/weak cough \\
& Exaggerated jaw jerk/facial jerks & Palatal weakness/nasal escape \\
& Spastic tetraparesis & Wasting/weakness/fasciculation of sternomastoid \\
& Extensor plantar response(s) & Wasting/fasciculation C2-T1 \\
Cervical & Reflexes present in a wasted limb & Paradoxical breathing/diaphragmatic palsy \\
& Finger jerks & Absent upper limb reflexes \\
& Spastic tetraparesis/extensor & plantar(s),without bulbar signs \\
Thoracic & Spastic paraparesis & Paraspinal/abdominal fasciculation \\
& Extensor plantar response(s) & Paraspinal wasting, truncal weakness \\
Lumbo/sacral & & Intercostal weakness/reduced vital capacity \\
& & Wasting/fasciculation L2-S2 \\
& & Absent lower limb reflexes \\
\hline
\end{tabular}

clinical pattern of the MND as follows: (1-1) $A L S / P B P$ Clinically definite MND which began with limb symptoms but later developed bulbar features.

(1-2) $P B P / A L S$ Clinically definite MND which began with bulbar symptoms and later developed limb symptoms or began with bulbar and limb symptoms simultaneously.

\section{2) Clinically probable $M N D$}

(2-1) PBPA syndrome in which dysarthria and dysphagia of UMN or LMN origin are the predominant features (but which may be accompanied by sternomastoid weakness) in the absence of LMN limb signs but which may be accompanied by UMN limb signs (for example extensor plantar response) but not symptoms (for example difficulty in walking). (2-2) Spinal ALS (3 regions) and (2-3) Spinal $A L S$ (2 regions) Three and two regions (cervical, thoracic and lumbosacral) involved respectively with a combination of UMN and LMN signs, not necessarily both in the same region but without bulbar features and given the above qualifications, in particular exclusion of cervical spondylotic myelopathy. Patients registered with monomelic atrophy were not included in the calculation of incidence data. (2-4) PMA An exclusively LMN motor disorder affecting at least two regions and with a clearly progressive course supported by consistent neurophysiological investigations (see below).

(2-5) PLS An exclusively UMN motor system disorder (after at least two EMG examinations separated by at least six months) affecting all four limbs with or without involvement of the brainstem; in the absence of a family history of gait disturbance and with no evidence of multiple sclerosis or MND mimic syndromes after CSF immunological studies; visual evoked responses and MRI of the brain or cervical cord. Patients with unspecified spastic paraparesis were explictly excluded.

The above classification was applied firstly, either at registration based on the documented features of the illness when patients first came to medical attention, or, if patients were identified through hospital discharge or mortality data, retrospectively, again based on the features at medical presentation. Secondly, when the full extent of the disease was established after follow up, or all available data had been reviewed after death, whichever came first.
Criteria for neurophysiological diagnosis were not established prospectively and are difficult to apply rigorously given the variation in clinical practice between neurophysiologists. Particular attention was paid to the results of nerve conduction studies and EMG where available to:

1) Exclude other causes of LMN disease, particularly polyneuropathies, compressive neuropathies or radiculopathies, multifocal motor neuropathy ${ }^{16}$ and myopathies.

2) Identify LMN involvement which was not evident on clinical examination and which could therefore be used to assist subgroup classification. Equal weight was given to the finding of LMN abnormalities on EMG as to the clinical LMN signs (table 2) when determining the extent of regional involvement.

3) A means of documenting the spread of LMN abnormalities and therefore the progressive nature of the disease.

Myelography was usually performed when the diagnosis was probable rather than definite. Most patients had a CSF examination. In some instances support for the diagnosis was obtained with swallowing tests (barium cine swallow) and muscle biopsy. Antiganglioside antibodies were not routinely performed.

The diagnosis was considered proven by postmortem examination if this showed: LMN and UMN neuronal loss in the brainstem or spinal cord and neuronal atrophy with loss of Nissl substance, corticospinal tract degeneration and the absence of extensive central chromatolysis, active neuronophagia, neurofibrillary tangles, abnormal storage material, spongiform change and extensive inflammation.

\section{Results}

Initially, a total of 123 patients were registered but nine patients were not included in the incidence analysis because the diagnosis did not fulfil the above criteria. Either MND coexisted with other neurological disease or the diagnosis was subsequently shown not to be MND. One hundred and fourteen patients with definite or probable MND were diagnosed in 1989. Many patients were notified from multiple sources but the first source of referral was as follows: 68 patients by collaborating neurologists and neurophysiologists; 24 from hospital discharge data; 10 by SMNDR family care officers; nine by GPs; two from 
Table 3 Clinical classification at presentation and based on data as of May 1991

\begin{tabular}{|c|c|c|c|c|c|c|}
\hline & $\begin{array}{l}\text { At presentation } \\
\text { Men }\end{array}$ & Women & Total & $\begin{array}{l}\text { May } 1991 \\
\text { Men }\end{array}$ & Women & Total \\
\hline $\begin{array}{l}\text { Clinically definite MND } \\
1-1 \text { Beginning in the limbs (ALS/PBP) } \\
1-2 \text { Beginning in the bulbar muscles(PBP/ALS) }\end{array}$ & $\begin{array}{r}10 \\
8\end{array}$ & $\begin{array}{l}15 \\
16\end{array}$ & $\begin{array}{l}25 \\
24\end{array}$ & $\begin{array}{r}21 \\
8\end{array}$ & $\begin{array}{l}17 \\
21\end{array}$ & $\begin{array}{l}38 \\
29\end{array}$ \\
\hline $\begin{array}{l}\text { Clinically probable MND } \\
\text { 2-1 Progressive bulbar palsy (PBP) } \\
\text { 2-2 Spinal amyotrophic lateral sclerosis (ALS) (3 regions) } \\
\text { 2-3 Spinal ALS ( } \text { regions) } \\
\text { 2-4 Progressive muscular atrophy (PMA) } \\
\text { 2-5 Primary lateral sclerosis (PLS) } \\
\text { Total }\end{array}$ & $\begin{array}{r}1 \\
28 \\
11 \\
4 \\
0 \\
62\end{array}$ & $\begin{array}{r}7 \\
9 \\
4 \\
1 \\
0 \\
52\end{array}$ & $\begin{array}{r}8 \\
37 \\
15 \\
5 \\
0 \\
114\end{array}$ & $\begin{array}{r}1 \\
23 \\
7 \\
2 \\
0 \\
62\end{array}$ & $\begin{array}{r}2 \\
7 \\
4 \\
1 \\
0 \\
52\end{array}$ & $\begin{array}{r}3 \\
30 \\
11 \\
3 \\
0 \\
114\end{array}$ \\
\hline
\end{tabular}

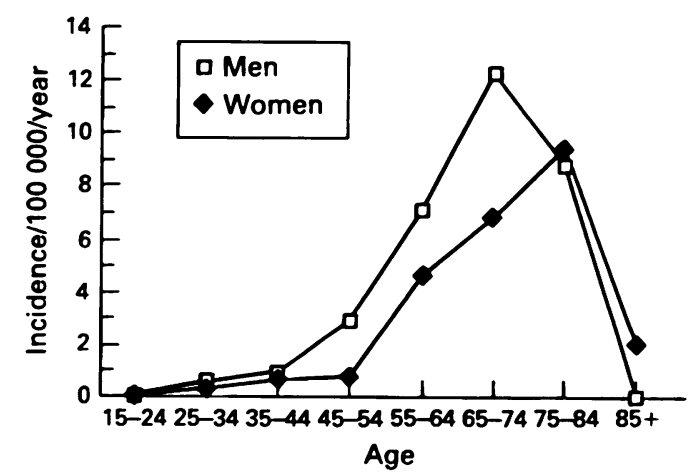

Figure 1 Age-sex specific incidence rates for motor neuron disease (Scotland 1989).

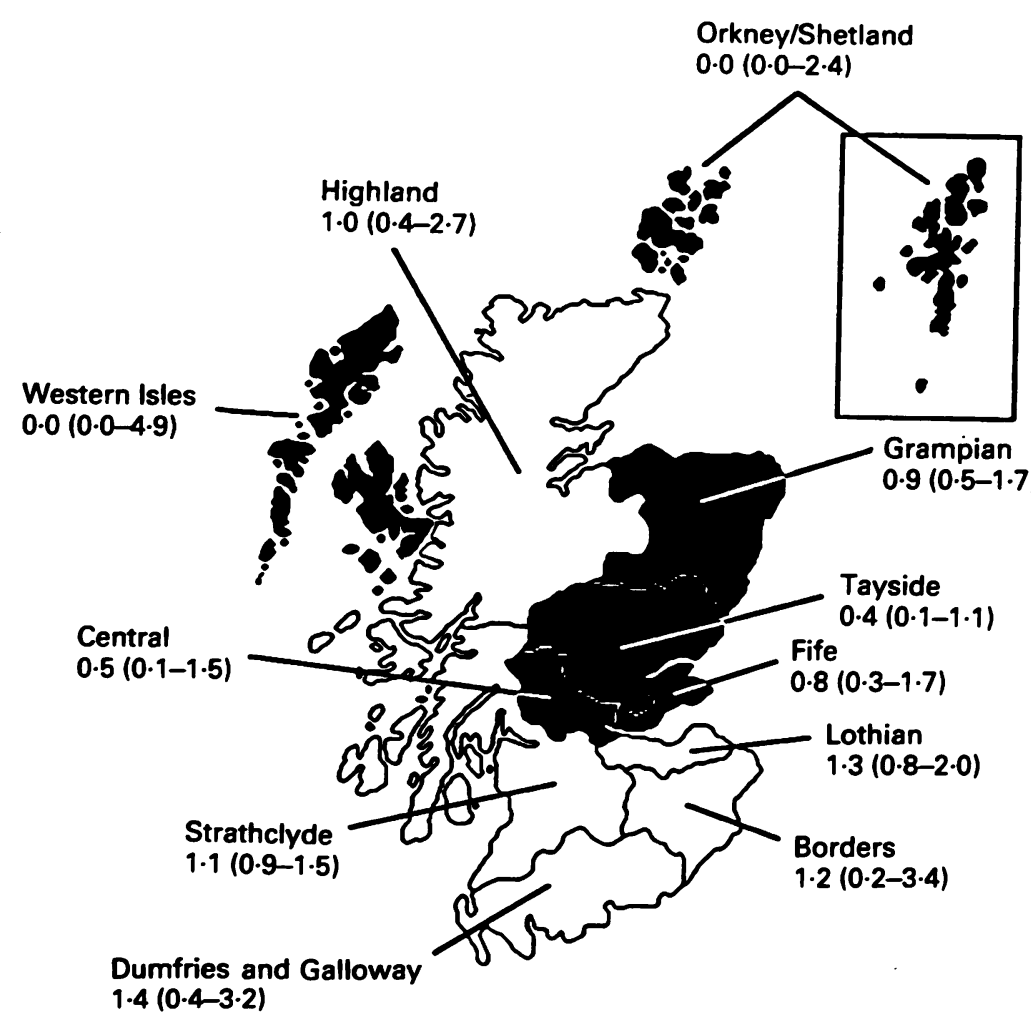

Less than 1

Greater than 1

Figure 2 Distribution of motor neuron disease (Scotland) 1989. Standardised incidence ratios (95\% confidence intervals). mortality records; and one from pathology records. Ninety two patients $(81 \%)$ had been seen at some time by a neurologist and 95 $(83 \%)$ had had an EMG.

Sixty two patients $(54 \%)$ were men [mean (SD) age at diagnosis $62.5(12 \cdot 4)$ range $27-84$ years], $52(46 \%)$ were women [mean (SD) age at diagnosis $68 \cdot 0(12 \cdot 1)$ range $31-91$ years], giving a male to female ratio of $1 \cdot 2: 1$. The difference in ages was significant $(5 \cdot 5$ years, 95\% CI $0 \cdot 9-10 \cdot 1$ ).

The classification of the patients' clinical status, is given in table 3. Patients with PBP and PMA only at onset were in the minority and most individuals presenting with PBP evolved into the PBP/ALS group. Six patients (5\%) had a family history of MND but none was related to each other.

The crude incidence for Scotland was $2 \cdot 24 / 100000 /$ year (95\% CI $1 \cdot 83$ to $2 \cdot 65$ ). Age and sex specific incidence rates (presented in table 4) continued to rise to a peak between 75-84 years for women and 65-74 years for men (fig 1). The number of patients older than 85 years was very small making interpretation of rates in the very elderly difficult. The age adjusted standardised incidence ratios for individual regions showed some variation (fig 2). Ninety five per cent confidence limits overlapped with unity, however, indicating none was significantly different from the expected at the $\mathrm{p}<0.05$ level, although lower standardised ratios were observed in the north east and island areas.

\section{Discussion}

The epidemiological method may provide important clues to the causes of MND by demonstrating temporal and geographical trends in distribution. Difficulties arise in delineating the optimum size for such a study: under-reporting and error in diagnosis will bias mortality studies based on very large populations, whereas random variation will lead to imprecise estimates if a sample used is too small. In this study, which will continue to accrue registrations, the size has not compromised diagnostic accuracy because data can be sought prospectively. The population base is such that a useful number of patients can be registered within a few years and thereby offers the opportunity to provide a valuable long term study of MND in Scotland. In addition, the methods of the SMNDR are unique with 
Table 4 Age-sex specific incidence rates for MND in Scotland (1989). The numbers of patients are given in five year age bands, incidence and $95 \%$ confidence interval (CI) is calculated for 10 year age bands for the mid-decades.

\begin{tabular}{|c|c|c|c|c|c|c|c|c|c|}
\hline $\begin{array}{l}\text { Age } \\
\text { band }\end{array}$ & Population & $n$ & $\begin{array}{l}\text { Men } \\
\text { Incidencel } \\
100000 / y r \\
(95 \% \text { CI })\end{array}$ & Population & $n$ & $\begin{array}{l}\text { Women } \\
\text { Incidencel } \\
100000 / y r \\
(95 \% \text { CI })\end{array}$ & Population & $n$ & $\begin{array}{l}\text { Total } \\
\text { Incidencel } \\
100000 / y r \\
(95 \% \text { CI })\end{array}$ \\
\hline $15-24$ & 4071870 & $(0)$ & \multirow[t]{2}{*}{$\begin{array}{l}0.00 \\
(0.00-0.73)\end{array}$} & 391983 & $(0)$ & \multirow[t]{2}{*}{$\begin{array}{l}0 \cdot 00 \\
(0 \cdot 00-0 \cdot 76)\end{array}$} & 799853 & $(0)$ & \multirow[t]{2}{*}{$\begin{array}{l}0 \cdot 00 \\
(0 \cdot 000 \cdot 37)\end{array}$} \\
\hline $\begin{array}{l}25-29 \\
30-34\end{array}$ & $\begin{array}{l}210796 \\
184169\end{array}$ & $\begin{array}{l}(2) \\
(0)\end{array}$ & & $\begin{array}{l}201758 \\
182061\end{array}$ & $\begin{array}{l}(0) \\
(1)\end{array}$ & & $\begin{array}{l}412554 \\
366230\end{array}$ & & \\
\hline $25-34$ & 394965 & (2) & \multirow[t]{2}{*}{$\begin{array}{l}0.51 \\
(0 \cdot 10-1 \cdot 50)\end{array}$} & 383819 & (1) & \multirow[t]{2}{*}{$\begin{array}{l}0 \cdot 26 \\
(0 \cdot 10-1 \cdot 20)\end{array}$} & 778784 & (3) & \multirow[t]{2}{*}{$\begin{array}{l}0.38 \\
(0.19-0.90)\end{array}$} \\
\hline $\begin{array}{l}35-39 \\
40-44\end{array}$ & $\begin{array}{l}167833 \\
172561\end{array}$ & $\begin{array}{l}(0) \\
(3)\end{array}$ & & $\begin{array}{l}168056 \\
172776\end{array}$ & $\begin{array}{l}(1) \\
\text { (1) }\end{array}$ & & $\begin{array}{l}335889 \\
345337\end{array}$ & & \\
\hline $35-44$ & 340394 & (3) & \multirow[t]{2}{*}{$\begin{array}{l}0 \cdot 88 \\
(0 \cdot 27-2 \cdot 10)\end{array}$} & 340832 & (2) & \multirow[t]{2}{*}{$\begin{array}{l}0.59 \\
(0 \cdot 27-1 \cdot 70)\end{array}$} & 681226 & (5) & \multirow[t]{2}{*}{$\begin{array}{l}0.73 \\
(0.09-1 \cdot 38)\end{array}$} \\
\hline $\begin{array}{l}45-49 \\
50-54\end{array}$ & $\begin{array}{l}144006 \\
136881\end{array}$ & $\begin{array}{l}(5) \\
\text { (3) }\end{array}$ & & $\begin{array}{l}149071 \\
145717\end{array}$ & (1) & & $\begin{array}{l}293077 \\
282598\end{array}$ & & \\
\hline $45-54$ & 280887 & (8) & \multirow[t]{2}{*}{$\begin{array}{l}2 \cdot 85 \\
(0 \cdot 87-4 \cdot 80)\end{array}$} & 294788 & (2) & \multirow[t]{2}{*}{$\begin{array}{l}0.68 \\
(0.31-1.97)\end{array}$} & 575675 & (10) & \multirow[t]{2}{*}{$\begin{array}{l}1 \cdot 74 \\
(0 \cdot 60-2 \cdot 81)\end{array}$} \\
\hline $\begin{array}{l}55-59 \\
60-64\end{array}$ & $\begin{array}{ll}131 & 201 \\
123 & 114\end{array}$ & $\begin{array}{r}(11) \\
(7)\end{array}$ & & $\begin{array}{l}144283 \\
141079\end{array}$ & $\begin{array}{l}(6) \\
(7)\end{array}$ & & $\begin{array}{l}275484 \\
264193\end{array}$ & & \\
\hline $55-64$ & 254315 & (18) & \multirow[t]{2}{*}{$\begin{array}{l}7 \cdot 08 \\
(3 \cdot 81-10 \cdot 30)\end{array}$} & 285362 & (13) & \multirow[t]{2}{*}{$\begin{array}{l}4 \cdot 56 \\
(2 \cdot 10-7 \cdot 03)\end{array}$} & 539677 & (31) & \multirow[t]{2}{*}{$\begin{array}{l}5 \cdot 74 \\
(3 \cdot 72-7 \cdot 77)\end{array}$} \\
\hline $\begin{array}{l}65-69 \\
70-74\end{array}$ & $\begin{array}{r}113212 \\
73196\end{array}$ & $\begin{array}{r}(14) \\
(9)\end{array}$ & & $\begin{array}{l}141953 \\
106321\end{array}$ & $\begin{array}{l}(9) \\
(8)\end{array}$ & & $\begin{array}{l}255165 \\
179517\end{array}$ & & \\
\hline $65-74$ & 186408 & (23) & \multirow[t]{2}{*}{$\begin{array}{l}12 \cdot 30 \\
(7 \cdot 30-17 \cdot 40)\end{array}$} & 248274 & (17) & \multirow[t]{2}{*}{$\begin{array}{l}6 \cdot 85 \\
(3 \cdot 60-10 \cdot 10)\end{array}$} & 434682 & (40) & \multirow[t]{2}{*}{$\begin{array}{l}9 \cdot 20 \\
(6 \cdot 35-11 \cdot 21)\end{array}$} \\
\hline $\begin{array}{l}75-79 \\
80-84\end{array}$ & $\begin{array}{l}59099 \\
31927\end{array}$ & $\begin{array}{l}(6) \\
(2)\end{array}$ & & $\begin{array}{ll}99 & 573 \\
70 & 064\end{array}$ & $\begin{array}{r}(10) \\
(6)\end{array}$ & & $\begin{array}{l}158672 \\
101991\end{array}$ & & \\
\hline $75-84$ & 91026 & (8) & \multirow{3}{*}{$\begin{array}{l}8 \cdot 79 \\
(2 \cdot 70-14 \cdot 90) \\
0 \cdot 00 \\
(0 \cdot 00-20 \cdot 00) \\
2 \cdot 52 \\
(1 \cdot 89-3 \cdot 15)\end{array}$} & 169637 & (16) & \multirow{3}{*}{$\begin{array}{l}9 \cdot 43 \\
(4 \cdot 81-14 \cdot 10) \\
1 \cdot 99 \\
(0 \cdot 80-8 \cdot 90) \\
1.90 \\
(1 \cdot 37-2 \cdot 43)\end{array}$} & 260663 & (24) & \multirow{3}{*}{$\begin{array}{l}9 \cdot 20 \\
(5 \cdot 52-12 \cdot 90) \\
1 \cdot 50 \\
(0 \cdot 60-6 \cdot 90) \\
2 \cdot 24 \\
(1 \cdot 83-2 \cdot 65)\end{array}$} \\
\hline$>85$ & 14979 & (0) & & 50306 & (1) & & 65285 & (1) & \\
\hline Total & 2460373 & $(62)$ & & 2630327 & $(52)$ & & 5090700 & (114) & \\
\hline
\end{tabular}

its prospective, collaborative design recruiting incident patients from multiple sources to achieve complete case acertainment with detailed clinical records and follow up of an unbiased sample. In this way accurate data will be obtained over several years concerning temporal trends, demography and prognosis in MND.

Some studies of incidence or clinical features in MND have relied on data collected from tertiary referral centres, ${ }^{1720}$ but generally, such studies give a lower incidence or a lower mean age or both than those which make a more concerted effort in case finding. One of the most comprehensive, but retrospective, studies was conducted in Rochester, Minnesota. $^{2122}$ Forty four patients were included in that population based study between 1925-84 giving a crude incidence of $2 \cdot 0 / 100000$ /year (95\% CI 1.4 to $2 \cdot 7$ ). The incidence of MND has been examined in a number of other countries but in only two, both from Scandinavia, ${ }^{2324}$ the crude incidence was higher than our study. The denominators, however, were not provided so it is difficult to make a satisfactory comparison because of possible differences in age structure of the population at risk. A previous study of the incidence of MND in Scotland ${ }^{25}$ based on unverified hospital discharge data (1968-77), and therefore likely to be contaminated with diseases other than MND, gave a high crude average first discharge rate of $4 \cdot 7 / 100000 /$ year and $3.01 / 10000 /$ year for men and women respectively. Mortality statistics collected over the same period gave average rates of $1 \cdot 57 / 100000 /$ year and $1 \cdot 18 / 100000 /$ year respectively. A further incidence study confined to the Lothian region ${ }^{26}$ was incomplete in tracing case records and reported a range of incidence over $1968-75$ of 1.0 to $1 \cdot 9 / 100000 /$ year.

All studies that have examined age specific incidence, except the Rochester study, found a decline in rates in the elderly age group. Our data show that the highest age specific incidence of $9 \cdot 2 / 100000 /$ year for men and women combined (see table 4 ) was maintained into the 75-84 year age group. The decline in rates over 85 years is difficult to interpret due to the small numbers but may be due to failure to diagnose the illness in this age group rather than poor ascertainment of diagnosed patients. If rates really do continue to rise into old age rather than decline, as is generally reported, then senescence must make a major contribution to the development of MND.

Mortality data reflect incidence. MND is recorded as a cause of death in about $80 \%$ of clinically diagnosed patients ${ }^{27} 28$ and therefore may be a useful method for following trends in this disease. There is always a concern, however, that changing diagnostic practices, changes in the ICD, or increasing case ascertainment may be responsible for any observed changes. In addition, this method may not reflect true rates in the elderly and does not allow the study of clinical features and prognostic variables or case control studies.

Apart from the conspicuous exception of the south Pacific varieties of MND, ${ }^{29} 30$ which may have a separate aetiology to that observed in Western countries, ${ }^{3132}$ it has been claimed that the distribution of MND is uniform worldwide. $^{33-36}$ This concept has recently been challenged $^{8}$ but the low incidence observed in developing countries might relate to poor case ascertainment rather than any true difference in incidence. ${ }^{37}{ }^{38}$ There is some tentative evidence from the use of small area statistics, that clustering of cases within populations may occur, ${ }^{39}$ supporting numerous anecdotal reports of clusters. ${ }^{40-44}$ We have started examining the distribution of patients in Scotland but have no clear evidence of non-random distribution. Failure to demonstrate non-uni- 
formity may be due to the inadequate statistical power of our sample so far and it remains to be seen if the tendency for lower rates in the northeast and island areas will be confirmed as the years go by and more patients are recruited.

This work was supported by the Scottish Motor Neuron Disease Association (SMNDA). We thank Shona Henderson and Rita Walker, SMNDA family care officers, for their help; Miss C S Rae of the General Register Office for Scotland for her assistance with death certificate data; Dr Clarke of the information and statisitics division of the Common Services Agency for the Scottish Health Service for providing hospital data on patients discharged with a diagnosis of MND; the medical records staff of Scottish hospitals and the general practioners of Scotland (too numerous to name) without whose practioners of Scotland (too numerous

The manuscript was prepared by: Dr A M Chancellor, Dr R J Swingler, Ms H Fraser, Professor C P Warlow, Department of Clinical Neurosciences, Western General Hospital, Crewe Road, Edinburgh, UK.

1 Munsat TL, Skerry L, Korf B, et al. Phenotypic heterogeneity of spinal muscular atrophy mapping to chromosome 5q11.2-13.3 (SMA 5q). Neurology 1990; 40:1831-6.

2 Mulder DW, Kurland LT, Offord KP, Beard CM. Familial adult motor neuron disease: amyotrophic lateral sclerosis. Neurology 1986;36:511-7.

3 Siddique T, Figlewicz DA, Pericak-Vance MA, et al. Linkage of a gene causing familial amyotrophic lateral sclerosis to chromosome 21 and evidence of genetic-locus heterogeneity. $N$ Engl f Med 1991;324;1381-4.

4 Tandan R, Bradley WG. Amyotrophic lateral sclerosis: Part 2. Etiopathogenesis. Ann Neurol 1985;18:419-31.

5 Rowland LP. Motor neuron diseases and amyotrophic lateral sclerosis: research progress. TINS 1987;10: lateral

6 Williams DB, Windebank AJ. Motor neuron disease (amyotrophic lateral sclerosis). Mayo Clin Proc 1991;66:54-82.

7 Younger DS, Chou S, Hays AP, et al. Primary lateral sclerosis. A clinical diagnosis re-emerges. Arch Neurol 1988;45:1304-7.

8 Editorial. What causes motoneuron disease? Lancet 1990;336:1033-5.

9 Stanhope JM, Brody JA, Morris CE. Epidemiologic features of amyotropic lateral sclerosis and Parkinsonism-dementia in Guam, Mariana Islands. Int $\Im$ Epidemiol 1972;1: 199-210.

10 Steele JC, Guzman T. Observations about amyotrophic lateral sclerosis and the Parkinsonism-dementia complex of Guam with regard to epidemiology and etiology. Can $\mathfrak{f}$ Neurol Sci 1987;14:358-62.

11 Hawkes CH. Graham AJ. What cause motoneuron disease? (letter). Lancet 1991;337:180.

12 Whitaker J. Whitaker's Almanack, London: Joseph Whitaker and Sons Ltd, 121st ed. 1989:612-3.

13 The Registrar General. Annual Report for Scotland 1989. Edinburgh: Government Statistical Service General Register Office, 135th ed. 1989.

14 Gardner MJ, Altman DG. Calculating confidence intervals for relative risks, odds ratios, and standardised ratios and rates. In: Statistics with confidence-confidence intervals and statistical guidelines, London: $B M \mathcal{F}$ 1989;50-63.

15 Gardner SB, Winter PD, Gardner MJ. Confidence intervals analysis version 1.0 (personal computer software). London: BMF 1989.

16 Pestronk A, Cornblath DR, Ilyas AA, et al. A treatable multifocal motor neuropathy with antibodies to GM1 ganglioside. Ann Neurol 1988;24:73-8.

17 Bracco L, Antuono P, Amaducci L. Study of epidemiological and etiological factors of amyotrophic lateral
sclerosis in the province of Florence, Italy. Acta Neurol sclerosis in the province
Scand $1979 ; 60: 112-24$.

18 Salemi G, Fierro B, Arcara A, Cassata M, Castiglione MG, Savettieri G. Amyotrophic lateral sclerosis in Palermo, Italy: an epidemiological study. Ital f Neurol Sci 1989 10:505-9.
19 Lopez-Vega JM, Calleja J, Combarros O, Polo JM, Berciano $\mathrm{J}$. Motor neuron disease in Cantabria. Acta Neurol Scand 1988;77:1-5

$20 \mathrm{Li} \mathrm{T}-\mathrm{M}$, Alberman E, Swash M. Clinical features and associations of 560 cases of motor neuron disease. $\mathcal{F}$ Neurol Neurosurg Psychiatry 1990;53:1043-5.

21 Juergens SM, Kurland LT, Okazaki H, Mulder DW. ALS in Rochester, Minnesota, 1925-1977. Neurology 1980;30: 463-70.

22 Yoshida S, Mulder DW, Kurland LT, Chu CP, Okazaki H Followup study on amyotrophic lateral sclerosis in Rochester, Minn., 1925 through 1984. Neuroepidemiology 1986;5:61-70.

23 Gunnarsson LG, Palm R. Motor neuron disease and heavy manual labour: an epidemiologic survey of Varmland manual labour: an epidemiologic survey of Varmlanc

24 Murros K, Fogelholm R. Amyotrophic lateral sclerosis in Middle-Finland: an epidemiological study. Acta Neurol Scand 1983;67:41-7.

25 Holloway SM, Emery AEH. The epidemiology of motor neuron disease in Scotland. Muscle Nerve 1982;5:131-3.

26 Holloway SM, Mitchell JD. Motor neurone disease in the Lothian region of Scotland 1961-81. $\mathcal{F}$ Epidemiol Community Health 1986;40:344-50.

27 Hoffman PM, Brody JA. The reliability of death certificate reporting for amyotrophic lateral sclerosis. 7 Chronic Dis 1971;24:5-8.

28 Buckley J, Warlow C, Smith P, Hilton-Jones D, Irvine S, Tew JR. Motor neuron disease in England and Wales 1959-1979. I Neurol Neurosurg Psychiatry 1983;46: 197-205.

29 Gajdusek DC. Urgent opportunistic observations: the study of changing, transient and disappearing phenomena of medical interest in disrupted primitive human communities. CIBA Found Symp 1977;49:69-94.

30 Kurland LT. Geographic isolates: their role in neuroepidemiology. Adv Neurol 1978;19:69-82.

31 Bharucha NE, Schoenberg BS, Raven RH, Pickle LW, Byar DP, Mason TJ. Geographic distribution of motor neuron disease and correlation with possible etiologic factors. Neurology 1983;33:911-5.

32 Kurland LT. Amyotrophic lateral sclerosis and Parkinson's disease complex on Guam linked to an environmental neurotoxin. Trends Neurosci 1988;11:51-4.

33 Kurland LT, Choi NW, Sayre GP. Implications of incidence and geographic patterns on the classification of amyotrophic lateral sclerosis. In: Norris FH, Kurland LT, eds. Motor neuron diseases - research on amyotrophic lateral Motor neuron diseases-research on amyotrophic lateral
sclerosis and related disorders. New York and London: sclerosis and related disorders. New

34 Kurland LT. Epidemiologic investigations of amyotrophic lateral sclerosis III. A genetic interpretation of incidence and geographic distribution. Mayo Clin Proc 1957;32: 449-62.

35 Bobowick AR, Brody JA. Epidemiology of motor-neuron diseases. N Engl f Med 1973;288:1047-55.

36 Kurtzke JF. Epidemiology of amyotrophic lateral sclerosis In: Rowland $\mathrm{P}$, ed. Human motor neuron diseases. New York: Raven Press, 1982:281-302.

37 Olivares L, Esteban ES, Alter M. Mexican "resistance" to amyotrophic lateral sclerosis. Arch Neurol 1972;27: 397-402.

38 Cendrowski W, Wender $M$, Owsianowski $M$. Analyse epidemilogique de la sclerose laterale amyotrophique sur le milogique de la sclerose laterale amyotrophique sur le
territoire de la Grande-Polongne (English abstract). Acta territoire de la Grande-Polongn

39 Mitchell JD, Gibson HN, Gatrell A. Amyotrophic lateral sclerosis in Lancashire and South Cumbria, England, 1976-1986. A geographical study. Arch Neurol 1990;47: 875-80.

40 Sienko DG, Davis JP, Taylor JA, Brooks BR. Amyotrophic lateral sclerosis. A case-control study following detection of a cluster in a small Wisconsin community. Arch Neurol 1990;47:38-41.

41 Paolino E, Granieri E, Tola MR, Rosati G. Conjugal amyotrophic lateral sclerosis. Ann Neurol 1983;14:699.

42 Chad D, Mitsumoto H, Adelman LS, Bradley WG, Munsat TL, Zieper I. Conjugal motor neuron disease. Neurology 1982;32:306-7.

43 Hochberg FH, Bryan JA, Whelan MA. Letter; Clustering of amyotrophic lateral sclerosis (letter). Lancet 1974; 1:34.

44 Norris FH. Four northern California amyotrophic lateralsclerosis clusters. In: Rose FC, Norris FH, eds. Amyotrophic lateral sclerosis. New advances in toxicology and epidemiology. London: Smith-Gordon, 1990:19-21. 